\title{
Time and space
}

Cite as: CMAJ 2017 March 6;189:E370-1. doi: 10.1503/cmaj.161099

CMAJ Podcasts: article reading at https://soundcloud.com/cmajpodcasts/161099-enc

ulie had to take 18 months off from her medical studies because of metastatic cancer but was now in her first year of residency. She was only 28. I, too, was a young cancer survivor, diagnosed at 25. Julie and I connected.

She had never told her story before and, as I listened, it became clear to me that health care providers could learn a lot from her experience. I asked Julie if she wanted to submit an abstract to an upcoming conference, comparing and contrasting her experiences as a patient and a resident. She agreed.

As we walked on to the stage, I felt nervousness radiating from her. Not only was this the first time she had told her story in public, it was her first conference presentation. After a short introduction, I took my seat at the panelist table a few feet away, and she stepped to the podium to read the first of her three stories.

She started strong despite an occasional wavering in her voice, but as she began to recount the actions of her doctors explaining the size of the "mediastinal mass," her brown eyes filled with tears and one escaped down her cheek. She faltered. Quickly wiping the tear from her cheek, she stopped speaking and looked over at me, the panic on her face clearly visible.

I nodded encouragingly and whispered, "You're doing fine. Just keep going."

She read another line and faltered again, her voice cracking midsentence. Again, the pause and panicked look across at me.

"Just breathe," I whispered. "Take a few deep breaths. You are doing fine."

She continued to stare at me, eyelashes quivering, breathing deep and ragged, mumbling apologies under her breath as a silent room looked on.

"Just keep going. Never mind the tears... You are doing great."

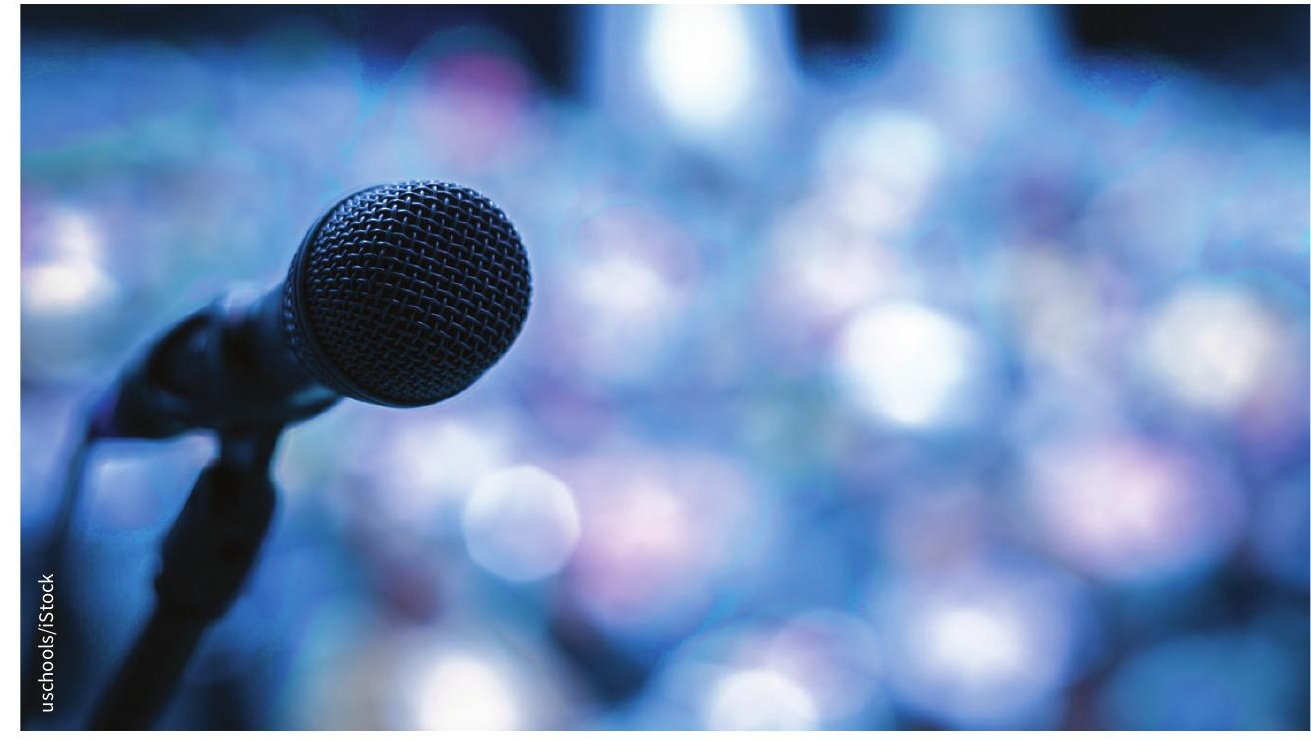

Julie managed to read all three short stories she had written about her cancer experience while the audience listened as still as a forest in the dead of winter. Afterwards, the applause seemed especially loud; the audience's questions especially heartfelt. But Julie was not able to respond to a single one, her wide-eyed look of horror barely disguised as she stood silently next to me at the podium.

As we stepped down from the stage and took our seats I whispered to her, "You did incredibly well."

With a dejected look she mumbled, "I feel so embarrassed," and turned quickly to her glass of water.

As the session wrapped up, I felt wretched. I wanted to debrief, to support her and the beautiful, vulnerable thing she had just done.

Once the session formally finished, I turned back to Julie, my mind whirling with words of affirmation, when I saw a wonderful palliative care physician already sitting next to her. The physician's hand was on Julie's arm as she talked qui- etly into her ear. I pretended like I was packing up my things so that I would be ready to jump in as soon as their conversation finished; however, as soon as it was, a third-year medical student knelt beside her chair and talked to her with an earnestness rarely seen in the medical or academic world. I turned to another conference attendee and made small talk, keeping an eye on Julie, but as soon as she was free of one conversation, she was immediately engaged in another. A constant stream of clinicians, researchers, administrators and academics came up to her for the next 20 minutes while I watched from a distance in agony, wondering what was happening and planning what I would say to encourage her. To reconcile with her. To save her from the harsh judgment that I had seen so often in the medical world.

Eventually, I looked over and she was alone, gathering her coat. I almost ran to her side, my mind full of all the things I would say to ease her embarrassment and suffering. 
"How are you feeling?" I said hesitantly. She picked up her purse and looked at me. "Well, I guess I will have to do this again."

"What? Really? Why?" I blurted out in choppy syllables.

"Well I can't stop now, not after all the incredible things people have just said to me! All of them shared a personal story about how cancer has impacted their lives... And they thanked me for sharing mine."

Dumbstruck, I stared stupidly into the big brown eyes that just minutes ago had been full of dejection and shame and saw instead a brightness, a steadiness, a newness. The kind of eyes that only show themselves when someone has received heartfelt affirmation from the people they respect and admire the most in this world. In that moment, I realized that a single experience of vulnerability, followed by sincere affirmation from a group of colleagues, can call into question a deeply ingrained sense of judgment and fear. I saw in Julie's eyes that health care providers have the capacity to not only heal the wounds of their patients but to heal each other's wounds as well; all that may be necessary is an honest story, and the time and space for an honest response.

\section{Michael Lang MSc}

Doctoral student, University of Calgary; Consultant, Engagement and Patient Experience, Alberta Health Services, Calgary, Alta.

This article has been peer reviewed.

This is a true story. The author obtained patient consent for it to be told, and the patient's name has been changed. 